\title{
The effect of fly ash on vegetative growth and photosynthetic pigment concentrations of rice and maize
}

\author{
S. S. Panda ${ }^{\star}$, \\ L. P. Mishra, \\ S. D. Muduli, \\ B. D. Nayak, \\ N. K. Dhal
}

Environment and Sustainability Department, CSIR-IMMT, Bhubaneswar-751013, India
Fly ash generated from coal based thermal power plants creates environmental problems due to improper utilization and disposal. The present study was conducted to study the effects of various concentrations of FA $(20,40,60,80$ and $100 \%)$ on the growth and photosynthetic activity of Oryza sativum (rice) and Zea mays (maize). Plant growth was mostly enhanced in the treatments with $20-40 \%$ fly ash, being optimal at $60 \%$. From $80 \%$ onwards, the measured parameters tended to reduce. The most economic level of fly ash incorporation was $60 \%$, which improved the growth of maize and rice. Hence fly ash can be utilized as a substrate or as a soil ameliorating material for the growth of plants, leading to the sustainable utilization of solid waste material.

Key words: fly ash, pot culture experiment

\section{INTRODUCTION}

Fly ash is an inorganic solid residue generated from thermal power plants through the burning of coal. In India, more than $70 \%$ of energy needs is met by coal based thermal power plants. Burning of coal releases oxides of nitrogen and sulfur and an enormous quantity of fly ash, which gets deposited on soil. Fly ash (FA) is a fine, glass powder of ferrous-aluminium silicate containing all of the essential elements that occur naturally in soil except humus and nitrogen. Chemically, 90-99\% of fly ash is comprised of $\mathrm{Si}, \mathrm{Al}, \mathrm{Fe}, \mathrm{Ca}, \mathrm{Mg}, \mathrm{Na}$ and $\mathrm{K}$ with $\mathrm{Si}$ and $\mathrm{Al}$ is forming the major matrix (Rees, Sidrak, 1956; Adriano et al., 1980). Mainly it contains $\mathrm{S}, \mathrm{B}, \mathrm{Ca}, \mathrm{Mg}, \mathrm{Fe}, \mathrm{Cu}, \mathrm{Zn}, \mathrm{Mn}$, and $\mathrm{P}$,

\footnotetext{
*Corresponding author. E-mail: swati.sucharita8@gmail.com
}

which are beneficial for plant growth, as well as toxic metals such as $\mathrm{Cr}, \mathrm{Pb}, \mathrm{Hg}, \mathrm{Ni}, \mathrm{V}$, As, and $\mathrm{Ba}$ (Elseew et al., 1980; Dalmau et al., 1990). About 112 million tons of fly ash are being generated annually in India by thermal power plants (Dhadhu, 2008). FA production depends on the quality of the coal, which contains a relatively high proportion of ash that leads to $10-30 \%$ FA formation (Meij, 1995; Singh, Siddiqui, 2003). The disposal of FA by conventional methods leads to degradation of arable land and contamination of ground water; hence an eco-friendly way of disposal becomes essential to derive the maximum benefit from its heterogeneous nature as it has several macro- and micronutrients (Gupta et al., 2002).

The present study deals with the effect of the application of varying levels of fly ash amended with soil on the growth of rice and maize. 


\section{MATERIALS AND METHODS}

\section{Sample collection of fly ash}

Fly ash was collected from the fly ash dump site of a coal based thermal power plant of the $\mathrm{Na}$ tional Thermal Power Corporation (NTPC) located at Kaniha, Talcher, Odisha (India). The power plant is located at $25^{\circ} 27^{\prime}-26^{\circ} 13^{\prime} \mathrm{N}$ latitude and $85^{\circ} 27^{\prime}-86^{\circ} 01^{\prime} \mathrm{E}$ longitude. For the experimental work, soil was collected from the agricultural field up to a depth of $20 \mathrm{~cm}$, after scrapping of the surface litters. Before utilization, the soil was steam sterilized keeping in gunny bags in an autoclave at $20 \mathrm{lb}$ pressure for 20 minutes. The autoclaved soil was dried and then mixed with fly ash in different percentage of $20,40,60,60$ and 100 separately.

\section{Physicochemical analysis of fly ash}

Fly ash and soil samples were air dried and analyzed for texture (Allen, 1974). EC and pH were determined by using a Hannes electrode. The estimation of organic carbon and phosphorus was determined by a slight modification of the method (Piper, 1950; Jackson, 1973), the sample was prepared for elemental analysis and analyzed with an atomic absorption spectrophotometer (McGrath, 1986).

\section{Experimental procedures}

For the experiments, fly ash was mixed with the autoclaved soil in the following percentage:

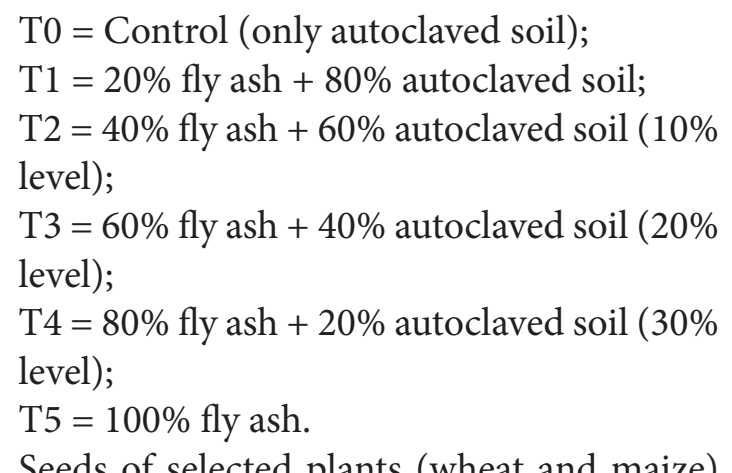

Seeds of selected plants (wheat and maize) were procured from Orissa Seeds Cooperation Ltd. Seeds were treated with $0.1 \%$ mercuric chloride for 5 minutes, followed by $70 \%$ alcohol for 1 minute. The sterilized seeds were thoroughly washed with distilled water.
The seeds were soaked for 48 hours before sowing. The pots were kept on the glasshouse bench at $25-27^{\circ} \mathrm{C}$. The seeds were transplanted into $15 \mathrm{~cm}$ diameter pots and were arranged in a randomized block design on the glasshouse bench. After a different interval of time, plants were analyzed for various parameters such as length of shoot and root; fresh wt. and dry wt.; photosynthetic pigments. The data was analyzed statistically for significance.

\section{Analysis}

Random samples of the plants were taken from each replicate pot after 15, 30 and 45 days of sowing (DAS) for the analysis of growth parameters and photosynthetic pigments. 5 plants were collected randomly from each set of the study, i. e. uprooted carefully with their roots intact. The root and shoot portions were separated and washed with de-ionized water. Samples were now made moisture free and weighed quickly to obtain fresh weight (FW) in grams. After this the plant parts (roots and shoots) were kept in an oven running at $80{ }^{\circ} \mathrm{C}$ for 24 hours and the dry weights were recorded in grams. Chlorophyll-a, chlorophyll-b, total chlorophyll, pheophytin and carotenoid content were calculated on $(\mathrm{mg} / \mathrm{g})$ of the fresh weight tissue basis (Porra, 1989).

Lengths of root and shoot were separately measured. The roots and shoots of plants were separated and oven dried at $80{ }^{\circ} \mathrm{C}$ till constant weight. Fully expanded fresh leaves of plants were sampled randomly from each replicate plot for various biochemical analyses. Pigment contents were extracted from the leaf disc with $80 \%$ acetone and quantified according to the methods given by Machlachlan and Zalik (1963); Duxbury and Yentsch (1956). The foliar protein content was analyzed according to the method of Lowry et al. (1951) using bovine serum albumin as a standard.

\section{RESULTS AND DISCUSSION}

Fly ash has an alkaline $\mathrm{pH}$ of about 7.98, and EC is $581 \mu \mathrm{S} / \mathrm{cm}$ which might be due to the presence of high concentration of oxides of $\mathrm{Ca}$ and 
Table 1. Physico-chemical analysis

\begin{tabular}{c|c|c|c|ccc}
\hline Sample name & $\mathrm{pH}$ & $\mathrm{EC}, \mu \mathrm{S} / \mathrm{cm}$ & Organic carbon & \multicolumn{3}{c}{ Texture } \\
\hline \multicolumn{3}{c}{} & & Sand & Silt & Clay \\
\hline Fly ash & 7.98 & 581 & 2.9 & 86.3 & 12.41 & 1.28 \\
\hline Soil & 6.8 & 228 & 4.1 & 37.31 & 53.74 & 8.94 \\
\hline
\end{tabular}

$\mathrm{Mg}$ (Rai et al., 2000). Organic carbon is very low as compared to that of soil.

Fly ash, a residue of coal consumption, is primarily made up of oxides of $\mathrm{Al}$ and $\mathrm{Si}$, but also enriched with several other essential ( $\mathrm{Zn}$, $\mathrm{Fe}, \mathrm{Mn}, \mathrm{B}$ and $\mathrm{Mo}$ ) and non-essential metals $(\mathrm{Ni}, \mathrm{Cr}, \mathrm{Pb}, \mathrm{Al}, \mathrm{Si})$ as reflected in Table 2.

Table 2. Heavy metal analysis

\begin{tabular}{c|c|c}
\hline Metals & Soil & Fly ash \\
\hline Chromium $(\mathrm{Cr})$ & 0.049 & 0.02 \\
\hline Cobalt $(\mathrm{Co})$ & 0.0003 & 0.001 \\
\hline Iron $(\mathrm{Fe})$ & 3.46 & 12.68 \\
\hline Cadmium $(\mathrm{Cd})$ & $\mathrm{ND}$ & 0.005 \\
\hline Nickel $(\mathrm{Ni})$ & 0.003 & 2.05 \\
\hline Lead $(\mathrm{Pb})$ & 0.005 & 9.574 \\
\hline Mercury $(\mathrm{Hg})$ & $8.65 \mu \mathrm{g} / \mathrm{g}$ & $10.44 \mu \mathrm{g} / \mathrm{g}$ \\
\hline Arsenic $(\mathrm{As})$ & $14.64 \mu \mathrm{g} / \mathrm{g}$ & $3.61 \mu \mathrm{g} / \mathrm{g}$ \\
\hline
\end{tabular}

Germination is a prime plant-growth process; the effect of different concentrations of fly ash blended with soil on the germination of rice and maize is presented in Fig. 1. Germina- tion of rice occurs after 3 days of sowing in all the treatment, but in the case maize germination starts after 5 days, it might be due to a hard seed coat. Maximum germination was recorded in F3 (60\% FA) in rice and in T2 (40\%) in maize. A trend was observed that with an increase in the concentration of fly ash, seed germination decreases.

In the present study, no visible injury symptoms were observed in any of the treatments during the growth and development. With an increase in the concentration of fly ash, there is a gradual reduction in the growth parameters such as root and shoot length, fresh weight and dry weight (Fig. 2). Soil blended with 80 and $100 \%$ FA shows a negative effect. The retarded plant growth, as reflected by decrease in root and shoot lengths as well as fresh and dry weight, may be coupled with undesirable chemical properties of the FA, including low N and P contents (Mishra, Shukla, 1986; Wong, Wong, 1989). Reduction in root length may be due to compaction of $\mathrm{FA}$ particles which probably served as a physical

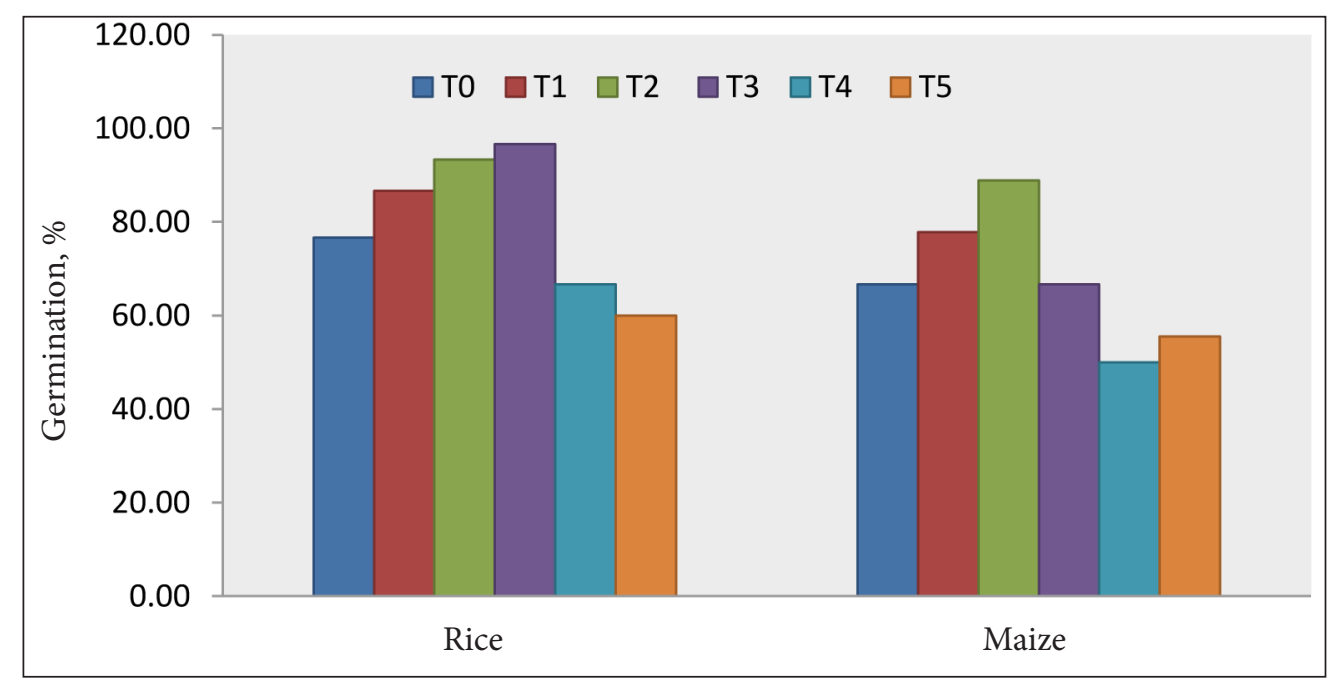

Fig. 1. Rate of germination in rice and maize 


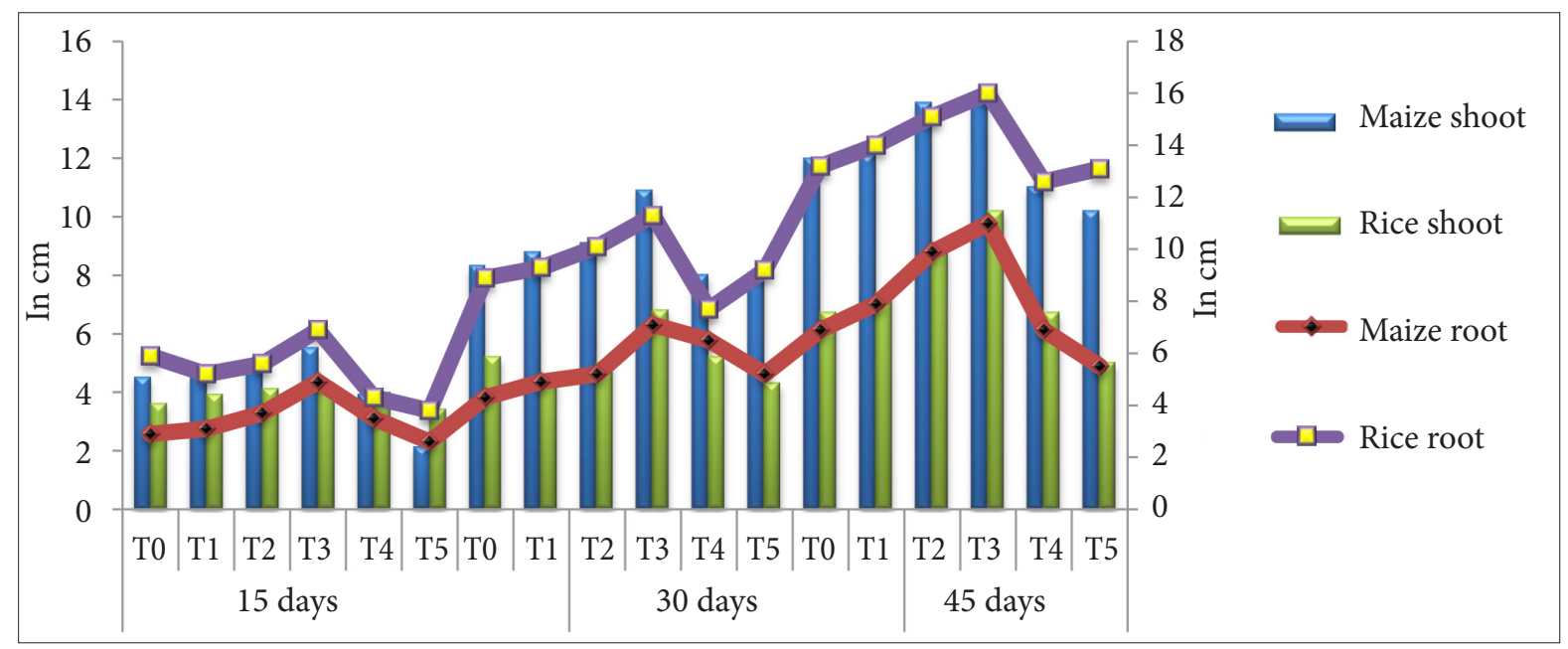

Fig. 2. Effect of different concentration of fly ash on the seedling growth, plant height in rice and maize in different intervals. Data are the mean of five replications

barrier to root elongation. Other studies have also shown that the high alkalinity affects the availability of nutrients, mainly phosphorous, which influence the plant growth adversely (Jala, Goyal, 2006).

Total chlorophyll and carotenoid contents also decreased significantly with increasing concentrations of FA as compared to that of the control at 30 DAS. Accumulation of heavy metals leads to inhibition of chlorophyll formation (Krupa, Baszynski, 1995).
Table 3. Photosynthetic pigment analysis in rice

\begin{tabular}{|c|c|c|c|c|c|}
\hline \multirow{2}{*}{ ڤ్ } & \multicolumn{5}{|c|}{$\begin{array}{l}\text { Photosynthetic pigments } \\
\text { (in } \mathrm{mg} / \mathrm{gm} \text { ) in rice }\end{array}$} \\
\hline & Chla & chlb & $\begin{array}{c}\text { Total } \\
\text { chl }\end{array}$ & $\begin{array}{l}\text { Pheo- } \\
\text { phytin }\end{array}$ & Carotenoid \\
\hline T0 & 2.46 & 2.82 & 5.32 & 0.89 & 0.26 \\
\hline T1 & 0.92 & 1.17 & 2.10 & 0.87 & 0.31 \\
\hline $\mathrm{T} 2$ & 1.80 & 2.15 & 3.98 & 0.76 & 0.42 \\
\hline T3 & 1.98 & 2.55 & 4.57 & 0.95 & 0.49 \\
\hline $\mathrm{T} 4$ & 1.92 & 2.42 & 4.38 & 0.73 & 0.35 \\
\hline T5 & 1.72 & 2.06 & 3.81 & 0.81 & 0.29 \\
\hline
\end{tabular}

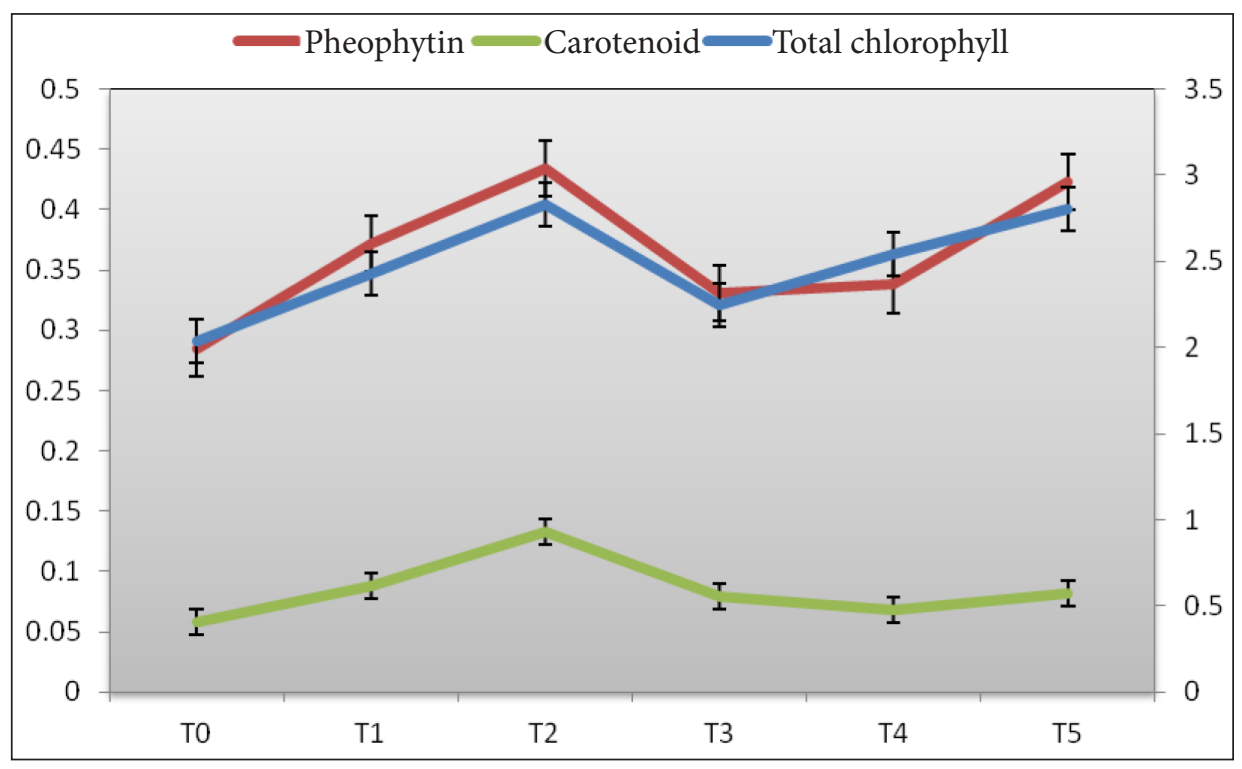

Fig. 3. Photosynthetic pigments (in $\mathrm{mg} / \mathrm{gm}$ ) in maize 
Fly ash application in soil improved the growth of rice and maize up to certain treatments, and after that, fly ash concentration caused deleterious effects on the plant growth. In our study, $40 \%$ fly ash levels proved to be optimally useful for the plant growth. The observed responses of the plants are also supported by other workers, like Bharti et al., on green gram; Pathan et al., on Cynodon dactylon (L.) Pers, Cv Wintergreen; Parveen et al., on Mentha citrata; Hisamuddin and Singh, on Pisum sativum. Their findings indicated that the concentration of fly ash for better plant growth varied from plant to plant. High levels of fly ash have caused toxic effects on plant growth. According to Kumar et al. and Rai et al., fly ash can be used as a fertilizer to improve soil fertility, especially for barren lands.

\section{CONCLUSIONS}

Based on the experiment, it can be concluded that there is an ample scope for the safe utilization of fly ash in agriculture without serious deleterious effects. But fly ash varied widely in its physical and chemical composition, therefore the mode of use in agriculture is different and depends on the characteristics of soil or soil type. The present study also suggests careful investigation of the accumulation of heavy metals (present in FA) in soil vis-a-vis in the edible portions of other vegetables.

\section{ACKNOWLEDGEMENTS}

The authors are grateful to the Director of CSIR-IMMT, Bhubaneswar, Odisha, India, for the constant encouragement and providing necessary facilities to carry out this research study. We are also thankful to the authority of the National Thermal Power Corporation (NTPC) located at Kaniha, Talcher, Odisha, for providing fly ash.

Received 16 March 2015 Accepted 22 July 2015

\section{References}

1. Adriano DC, Page AL, Elseewi AA, Chang AC, Straughan I. Utilization and disposal of fly ash and other coal residues in terrestrial ecosystems: a review. J Environ Qual. 1980; 9: 33344.

2. Allen SE. Chemical analysis of ecological materials. Oxford, UK: Blackwell Scientific Publications; $1974.565 \mathrm{p}$.

3. Bharti B, Matte DB, Badole WP, Deshmukh A. Effect of fly ash on yield, uptake of nutrients and quality of green gram grown on versitol. J Soils and Crops. 2000; 10: 122-4.

4. Dalmau JI, Garau MA, Felipo MT. Laboratory prediction of soluble compounds before soil recycling of wastes. Int J Environ Anal Chem. 1990; 39: 141-6.

5. Dhadhu S, Kumari P, Bhagia L. Fly ash characterization utilization and government initiative in India - a review. J Sci Ind Res. 2008; 67: 11.

6. Duxbury AC, Yentsch CS. Plankton pigment monographs. J Mar Res. 1956; 15: 91-101.

7. Elseewi AA, Straughan IR, Page AL. Sequential cropping of fly ash amended soil: effects on soil chemical properties and mineral composition of plants. Sci Total Environ. 1980; 15: 247-59.

8. Gupta DK, Rai UN, Tripathi RD, Inouhe M. Impacts of fly-ash on soil and plant responses. J Plant Res. 2002; 115: 401-40.

9. Halliwell B. Oxidative damage, lipid peroxidation and antioxidant protection in chloroplasts. Chem Phys Lipids. 1987; 44: 327-40.

10. Hisamuddin Singh S. 2007. Influence of rootknot nematode disease on yield and biomass production of Pisum sativum in fly ash amended soil [Abstract]. In: Proceedings of XXX All India Botanical Conference. 2007: 30.

11. Jackson ML. Nitrogen determination for soils and plant tissue: Soil chemical analysis. Prentice-Hall of India Private Limited; 1973.

12. Krupa Z, Baszynski T. Some aspect of heavy metals toxicity towards photosynthetic ap- 
paratus - direct and indirect effects on light and dark reactions. Acta Physiol Plant. 1995; 177-90.

13. Kumar V, Goswami G, Zakaria AK. 2001. Fly ash use in agriculture: issues and concerns. Technology demonstration projects commissioned by Fly Ash Mission under Technology Information Forecasting, Assessment Council (TIFAC) News and Views. 2006: 1-6.

14. Lowry OH, Rosenbrough FAL, Randall RJ. Protein measurement with Foiln phenol reagent. J Biol Chem. 1951; 193: 265-75.

15. Machlachlan S, Zalik S. Plastid structure, chlorophyll concentration and free amino acid composition of a chlorophyll mutant on barley. Can J Bot. 1963; 41: 1053-62.

16. Mathur R, Chans S, Tezukat T. Optional use of coal for the power generation in India. Energ Policy. 2003; 31: 319.

17. Mattigod SV, Rai D, Eary LE, Ainsworth CC. Geochemical factors controlling the mobilization of inorganic constituents from fossil fuel combustion residues: I. Review of the major elements. J Environ Qual. 1990; 19: 188-201.

18. McGrath SP, Sanders JR, Laurie SH, Tancock NP. Experimental determinations and computer predictions of trace metal ion concentrations in dilute complex solutions. Analyst. 1986; 111: 459-65.

19. Meij R. The distribution of trace elements during the combustion of coal. In: Swaine DJ, Goodarzi F, editors. Environmental aspects of trace elements in coal. Dordrecht, the Netherlands: Kluwer Academic Publication; 1995. p. 111-127.

20. Mishra LC, Shukla KN. Effects of fly ash deposition on growth, metabolic and dry matter production of maize and soybean. Environ Pollut (Series A). 1986; 42: 1-13.

21. Parveen R, Hisamuddin T, Azam T, Niyaz, Singh S. Effect of fly ash amended soil on the plant growth, yield, chlorophyll and oil content of Mentha citrata. In: Proceedings of the National Symposium on Issue and Challenges for Environmental Management. Vision. 2006; 2025: 55.

22. Pathan SM, Aylmore LAG, Colmer TD. Soil properties and turf growth on a sandy soil amended with fly ash. Plant Soil. 2003; 256: 103-14.

23. Piper CS. Soil and plant analysis. Adelaide, Australia: Hassel Press; 1950. 368 p.

24. Porra RJ, Thompson WA, Kriedmann E. Determination of accurate extinction coefficient and simultaneous equation for assaying chlorophyll standards by atomic absorption spectroscopy. Biochim Biophys Acta. 1989; 975: 384-94.

25. Rai UN, Tripathi RD, Singh N. Integrated biotechnological approach for phytoremediation of fly ash dyke [abstract]. In: Proceedings of 2nd International Conference on Plant and Environment Pollution. Lucknow, India: NBRI; 2002.

26. Rai UN, Tripathi RD, Singh N, Kumar A, Ali MB, Pal A, Singh SN. Amelioration of fly ash by selected nitrogen fixing blue green algae. Bull Environ Contam Toxicol. 2000; 64: 294-301.

27. Rees WI, Sidrak GH. Plant nutrition on fly ash. Plant Soil. 1956; 8: 141-53.

28. Singh LP, Siddiqui ZA. Effects of fly ash and Helminthosporium oryzae on growth and yield of three cultivars of rice. Bioresour Technol. 2003; 86: 73-8.

29. Tripathi A, Sahu RK. Effect of coal fly ash on growth and yield of wheat. J Environ Biol. 1997; 18(2): 131-5.

30. Wong $\mathrm{MH}$, Wong JWC. Germination and seedling growth of vegetable crops in fly ash amended soil. Agr Ecos Environ. 1989; 26: 23-35. 
S. S. Panda, L. P. Mishra, S. D. Muduli,

B. D. Nayak, N. K. Dhal

\section{SKRAIDANČIŲ PELENŲ POVEIKIS RYŽIŲ IR KUKURŪZŲ VEGETACINIAM AUGIMUI IR FOTOSINTETINIO PIGMENTO \\ KONCENTRACIJAI}

Santrauka

Netinkamas skraidančių pelenų (SP) iš anglimi kūrenamų šiluminių elektrinių panaudojimas ir utilizavimas kelia ekologinių problemų. Šis tyrimas skirtas įvairių koncentracijų (20, 40, 60, 80 ir $100 \%)$ SP poveikio ryžių Oryza sativum ir kukurūzų Zea mays vegetaciniam augimui ir fotosintezès aktyvumui ịvertinti. Augalai auginti pelenuose, kurių koncentracijos kas mėnesị buvo keičiamos. Didžiausias efektas nustatytas auginant $60 \%$ pelenuose, kur ryžių ir kukurūzų augimas padidèjo. Nustatyta, kad SP gali būti utilizuoti kaip substratas ar dirvožemị gerinanti medžiaga.

Raktažodžiai: skraidantys pelenai, vazoninių kultūrų eksperimentas 